\title{
FUND MANAGEMENT STRATEGY IN BAZNAS ZAKAT (AMIL ZAKAT NATIONAL AGENCY) EAST JAVA
}

Tika Widiastuti ${ }^{1}$, Wahyuningsih ${ }^{2}$, Imam Wahyudi Indrawan ${ }^{3}$

\begin{abstract}
* Affiliation:
${ }^{1}$ Department of Sharia Economics-Faculty of Economics and BusinessUniversitas Airlangga Email:

widasus@yahoo.com

${ }^{2}$ Department of Sharia Economics-Faculty of Economics and BusinessUniversitas Airlangga Email:

wahyuningsihayu75@ gmail.com

${ }^{3}$ Department of Sharia Economics-Faculty of Economics and BusinessUniversitas Airlangga Email:

imamindra58@gmail.com
\end{abstract}

\begin{abstract}
:
Poor people in the world remains a global problem. Previous studies have been widely using various perspectives related to aspects of fundamental and macroeconomic. However, research that focuses on methods to manage zakat institutions still do not exist. Especially on zakat management institutions in Indonesia. Countries with a Muslim majority population in the world. This study used a qualitative approach through multiple cases study aimed to determine the zakat fund management strategies at the National Zakat Agency and the Institute of National Zakat Al Ahzar East Java. Data collected through individual depth interview. This study describes the findings of Zakat Scorecard Model through categorical analysis results. The article also describes the academic and managerial implications related to zakat management institutions.
\end{abstract}

Keywords : Strategy Fund Management, BAZNAS and LAZNAS Al-Azhar Java, Zakat

\section{INTRODUCTION}

Poverty is a classic problem faced by the economies around the world. If measured using World Bank poverty standard of US \$ 1.25 per day per person (Ravallion et al.2008), then until 2014, there were $29 \%$ of the world population living in poverty or as much as 1.6 billion people. Problems of poverty also occurred in Indonesia. Since the second half of 2014 to 2016 East Java rank the first number of poor people in Indonesia. BPS data show as of the first semester of 2016, the number of poor people in East Java reached 4.703.3 thousand inhabitants of the total poor people in Indonesia amounted to 28.005.4 thousand inhabitants (CBS, 2016). On the other hand, economic growth in East Java (5.62\%) above the national average (5.18\%) in the second quarter (www.jpnn.com). This is the reason for the selection of East Java as an arena of the study authors. Because of the huge economic potential will be able to eradicate poverty. Then needed a way to reduce poverty. 
Has done much discussion of the poverty alleviation programs in the world. Included in Islam, there is Quran surah At-Tauba 103 which discusses the obligation of zakat as a means of allocating the rights of the poor are still contained in the wealth of the rich.Various research proves zakat role in the economy. Syed Othman Al-Ethiopia (1994) explains that the charity is able to create demand, it is becoming one of the major components in the calculation of Gross Domestic Product (GDP). On the other hand, Ahmed (2002) and Kahf (1990) describes the implementation of zakat which is also capable of providing microfinance to the poor.

Swiercz and Patricia Smith of the University of Georgia US also asserts that the best solution to the various problems facing traditional economic recession, as is currently afflict the US, is through the spirit and the mechanism of "sharing" between the components within an economy. The spirit of sharing is what will be able to maintain the level of prosperity of an economy. That is, there is a very strong correlation between giving and sharing, with the level of prosperity and well-being. Learning from these studies, it is only logical if the Indonesian people to optimize the potential of zakat, donation and charity, as a form of sharing economy is believed to have a positive impact building (Beik, 2008). One application of the concept of sharing economy, namely the management of zakat, infaq, and shodaqo.

Studies so far have not been answered regarding the implementation strategy zakat, infaq, shodaqoh of the world, especially with the theme of business strategy for the implementation of zakat, infaq, and shodaqah is the duty of this government in accordance with the statement Qaradawi (1973) in Indonesia Zakat and Development 2009 program, first, the management of zakat is part of the Muslim authorities, both state must split the balance of revenue and expenditure of zakat zakat. Third, the government is allowed to collect all kinds of Zakat and society must pay his zakat to the government for the government to distribute the zakat to mustahik, and fourth, the government's failure to distribute Zakat does not remove the obligation of zakat individually. Conclusion Four Qaradawi above statement is the entire implementation of the government waged zakat management resulting pelaksaanan study of zakat, infaq, shodaqoh of the world on the theme of business strategy has not been discussed.

Based on this background exposure, the problems can be formulated in this research is how the Zakat Fund Management Strategy in East Java BAZNAS? It became the first study to discuss the strategy for the management of zakat funds to bring research results on BAZNAS and LAZNAS in Indonesia.

\section{LITERATURE REVIEW}

\section{Zakat}

Indonesia as the largest Muslim country in the world is as it should have the greatest potential zakat collection anyway. Potential Zakat, Sadaqah Infak and in Indonesia in 2016 reached Rp217 trillion (baznas.go.id). Poverty contained in Indonesia from 2002 to 2014 steadily declining percentage, it means that there is positive progress is marked by decreasing the number of poor people. There amounted to 18.32 percent in 2002 to 2014 to 11.25 percent or experienced a significant decline in poverty for 12 years or from 2002 to 2014 in the amount of 62.84 percent. (Nugroho, 2014: 3). Management organization zakat in Indonesia are generally divided into two types, namely Badan Amil Zakat (BAZ) and the 
Institute Amil Zakat (LAZ). BAZ is zakat management organization under the auspices of the Government, while LAZ is zakat management organizations established by the public and private sectors (Najib Hamid, 2016).

Both institutions share the same spirit, namely to reduce poverty by channeling zakat, donation, shadaqah both consumptive and productive nature. Zakat consumptive meaning given to mustahik ZIS-mustahik already very old, unable to work, and their daily lives depend on the provision of other people. While productive Zakat is given to mustahik ZIS dirupakan into empowerment program to increase the added value, expertise and independence educate mustahik (Abdussalam, 2016),

\section{Strategy}

Rangkruti (2013: 3) explains that the strategy is a means to an end. Strategy comes from the Ancient Greek word is strategos who has a military connotation, which is an application of the art of science of war with military force to defeat the enemy or minimize the effects of the defeat. The strategy is a way to obtain the desired result based on prevailing conditions and structure. In principle, strategy can be grouped according to three types of strategies. First, Management Strategy. Management strategies include strategies that can be done by the management with the orientation of macro strategy development. Second, Investment Strategy. This strategy is an investment-oriented activities. Third, Business Strategy. This business strategy is also called functional business strategy because this strategy oriented to the functions of management activities (Rangkruti, 2013: 7)

\section{Balanced Scorecard}

This study uses a balanced scorecard framework approach (Kaplan and Norton, 2004). The first discusses the related learning and growth perspective, the strategy of the organization that manages the managerial system to continue to reform and growth towards a vision and mission. Secondly, the Internal perspective that focuses on the management processes of an organization to operationalize the company.

Third, the operational results of a customer-oriented perspective. The third perspective focuses on how to provide satisfaction to customers through a variety of aspects, including the price; quality; services and so forth. The latest results of the balanced scorecard is a financial perspective. As a profit-oriented organization, the company must have an end goal in improve the cost structure, and increase the value of company assets. This research led to the concept in managing zakat institutions using four perspectives. Because it can answer a variety of managerial processes comprehensively.

\section{METHOD \\ Data Collection}

The study used data collection techniques are divided into several stages. First, Preparation of materials and preparation of the interview schedule. This method was chosen because the Balanced Socorecard is a method that is considered capable of assessing the performance of the organization through the vision and strategy of the organization in real terms 
in the field who then will be able to be arranged into a model of the ideal strategy. As well as the study of literature as shown in Table 1 were used to create a tipping point in determining the appropriate question draft balanced scorecard framework. In addition to a literature study, the researchers also used Focused Group Discussion (FGD) according to table 1. Second, in-depth interviews. Interviews were conducted both openly and structured as well as the questions focused on the problem, so that the information collected is quite exhaustive. Data informants such as Table 1. Third, data archiving. Collecting data using several methods, such as in-depth interviews and observation. Fourth, data archive technique that uses electronic and written media (the minutes). Mechanical data archive is to use voice recorders and interview transcripts compiled from informants that previous studies had been appointed at the planning stage of the study. Fifth, observation. This observation techniques either directly or indirectly, or formally or informally used to observe various activities in empowering zakat zakat institutions in East Java. This is done in order to complete the data in the field of primary and secondary data collected previously, as well as secondary data.

\section{Purposive Sampling}

This study took a sample of informants directly corresponds researchers' choice. This was done to answer the research questions that can be obtained information from the management of zakat institution. Informants been where they are part of the core structure of zakat management organizations (OPZ), both the Institute Amil Zakat (LAZ), which is a representation of zakat institution owned by the community, and Badan Amil Zakat (BAZ) that represent government agencies have the zakat.

During the "theoretical saturation" still have not found a saturation, meaning that the characteristics of the answers of informants is still considered necessary to continue to be extracted, then the interview would teus carried out by the same source or with other informants who rated capable and knows the interview material that will be asked, until finally getting answers with identical patterns and repetitive.

Categorical Analysis

This study began the process of analyzing data from the identification data sources or informants, and selecting and grouping them into several classes. Where the informant class divisions based on years of service in the institution that they naungi, strktur position within the organization and insight and understanding of the performance of the institution or the organization as a whole. This approach presented by Gioia et al., 2010; Nag and Gioia, 2012; Strauss and Corbin, 1990.

\section{Insider-Outsider Approach}

This study conducted an interview with the core structure (head of the organization), also involves key informants whose background is a field force whose purpose is to assist in the processing of data by conducting focus group discussion (FGD), the discussion attended by many elements of the profession, such as academia, zakat practitioners, and media. Literature and the process used to determine the views of many experts related to the management of zakat in various countries 


\section{FINDING}

\section{Theme 1. Organization}

a. External Teamwork

Previous research states that the necessary alternative cross-agency cooperation, namely Takaful with BAZ and LAZ. It shows the cooperation between institutions or unit outside zakat institution. LAZ cooperation with units of volunteers in the implementation of disaster management. BAZ uses a partner in conducting its programs.

b. Cooperation Inter-Agency

Coordination becomes an important part in the management of zakat institution. LAZ using a centralized system in the collection of zakat funds. However BAZ use in a decentralized fashion fundraiser. But each of us can use the funds in accordance agency procedures.

\section{Theme 2. Information}

a. Effective Transaction Process

Zakat management that can effectively reduce poverty. Each BAZ and LAZ in their operation effectively use technological innovation.

b. Management Oversight

Supervision was conducted to determine the performance of the institution. LAZ and BAZ conduct surveillance through the flow of funds from muzakki income.

\section{Theme 3. Human}

a. Periodic Training

BAZ making regular training in financial management. While LAZ training to da'i will be deployed to the public.

b. Amil's Values

Values that must be owned by collectors, both in BAZ and LAZ, using the character development that attitude required to collect zakat. Among them is honesty and trust.

\section{Theme 4. Financial}

a. Improve Cash Flow

Each institution in developing the financial aspects of utilizing the branding strategy. LAZ using the name Al-Ahzar large in Indonesia. While the label mmemanfaatkan BAZ government agencies.

b. Customer Value Iniciativies

Initiative in giving value to muzakki very important for increasing the acquisition of zakat funds. How LAZ provide customer benefit can be invited to the village built muzakki. BAZ while exploiting the potential reduction in tax liability after paying zakat.

\section{Theme 5. Operation}

a. Real Sector Centric

Zakat is able to reduce poverty and grow the real sector. The process of reducing poverty do LAZ Al-Azhar via production house Gemilang Indonesia. While BAZNAS Jatim through 
scholarships and capital assistance for micro society. As well as the conduct of social programs such as disaster recovery and routine donations to the poor..

b. Equal "in-out" Distribution

Zakat institutions should be able to distribute over the acquisition of muzakki after deducting operating expenses. Each LAZ and BAZ perform effective operation and coordination between agencies.

c. Risk Management

Strategies to manage risks, carried out through maintaining the stability of institutions, and periodic audits of all managerial sectors in BAZ and LAZ.

d. Voting System

Scheme of community funds become crucial. LAZ facilitate that personal touch by telephone. While BAZ exploit the potential that is already available in the social culture of the society.

\section{Theme 6. Customer}

a. Specific Selection

Then selection mustahik muzaki and must be specific to be effective and efficient. LAZ Al-Ahzar use system Unit Operating Procedure (SOP) in selecting mustahik. As well as facilitating Java BAZNAS special models for muzakki pledge to provide funds infaq.

b. Growth

The growth process can be done in three ways. First, increase the amount of funding is done through education (LAZ) and take advantage of the momentum (BAZ). Second, increase the number of employees targeted muzakki through government agencies (BAZ). Third, distribute ZIS funds effectively through RGI (LAZ) and cooperation with partners through the monitoring mechanism (BAZ)

\section{Theme 7. Inovasi}

a. Iniciative Acceleration

Zakat management requires initiative in improving acquisition, including determining the target muzakki. In addition to determining the muzakki initiatives, strategies to help mustahik can be done through the formation of self help groups.

b. Public Education

One other important part is the process of dissemination to the public. LAZ do amil individually, while BAZ programs through the facility.

c. Tax Principle

Each institution to facilitate the administration of the tax reduction system.

\section{Theme 8. Social}

a. Islamic Community Building

Awareness pay zakat can realize a more Islamic life. One of these charity-related regulations at the state level. One example occurred in BAZ and LAZ is formed to muzakki mentoring, and building a community for mustahik which continually given training and religious knowledge. 
b. Communication

Communication is done routinely to muzakki and mustahik to maintain the intensity of interaction that will impact on improving public confidence.

\section{Theme 9. Mustahik}

a. Evaluasi

Evaluations were conducted dalah assess the needs of zakat funds. It can be done through cross zakat to the needy areas. Evaluation on BAZ done once a year for the entire management of se-national."

b. Keep Relationship

Keeping feelings mustahik an important part in the distribution of zakat. This is done through a personal approach and program.

\section{Theme 10. Muzakki}

a. Service Innvaation

Innovation through ease of service done through bank deposit and take advantage of the counter and the event..

b. Supporting Partner

"The focus will be on how the zakat fund has been used to finance economic activities or projects run by poor and needy people as part of a long-term rehabilitation program" (Abdullah, 2012). Supporting partner muzakki done through mentoring and collaboration partners.

c. Reporting

Each using a bulletin publishing strategy to provide financial reporting. In addition, the LAZ also displays the report through the website.

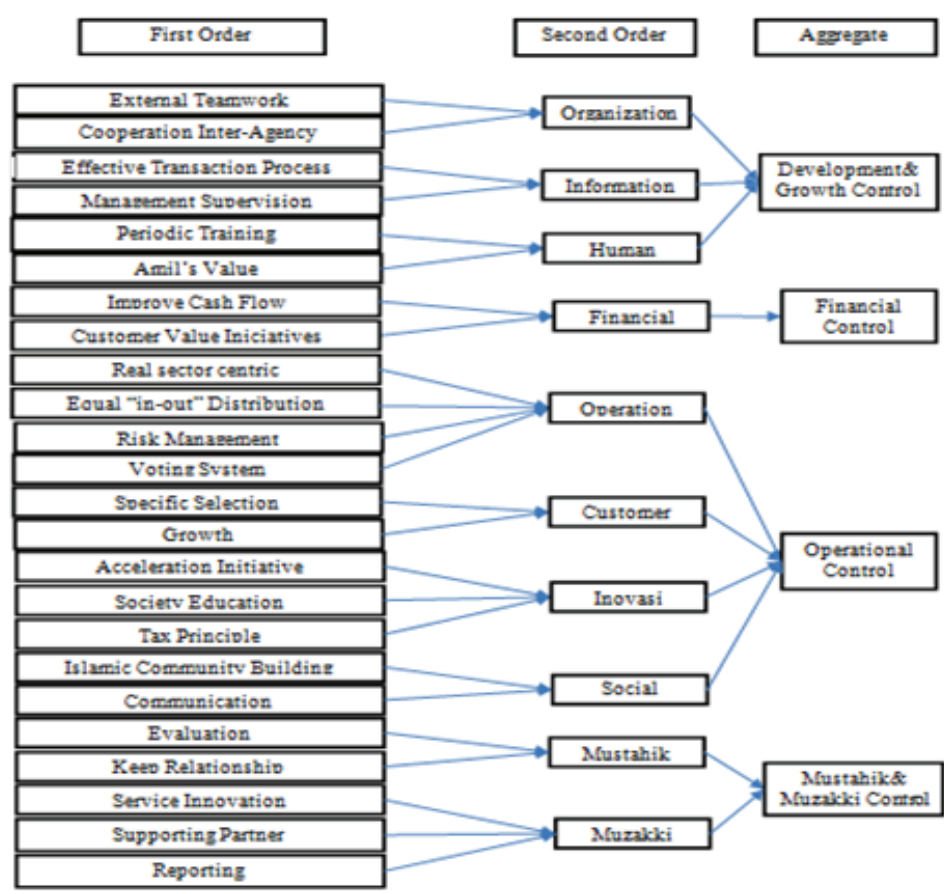

Picture 1. Data Structure 


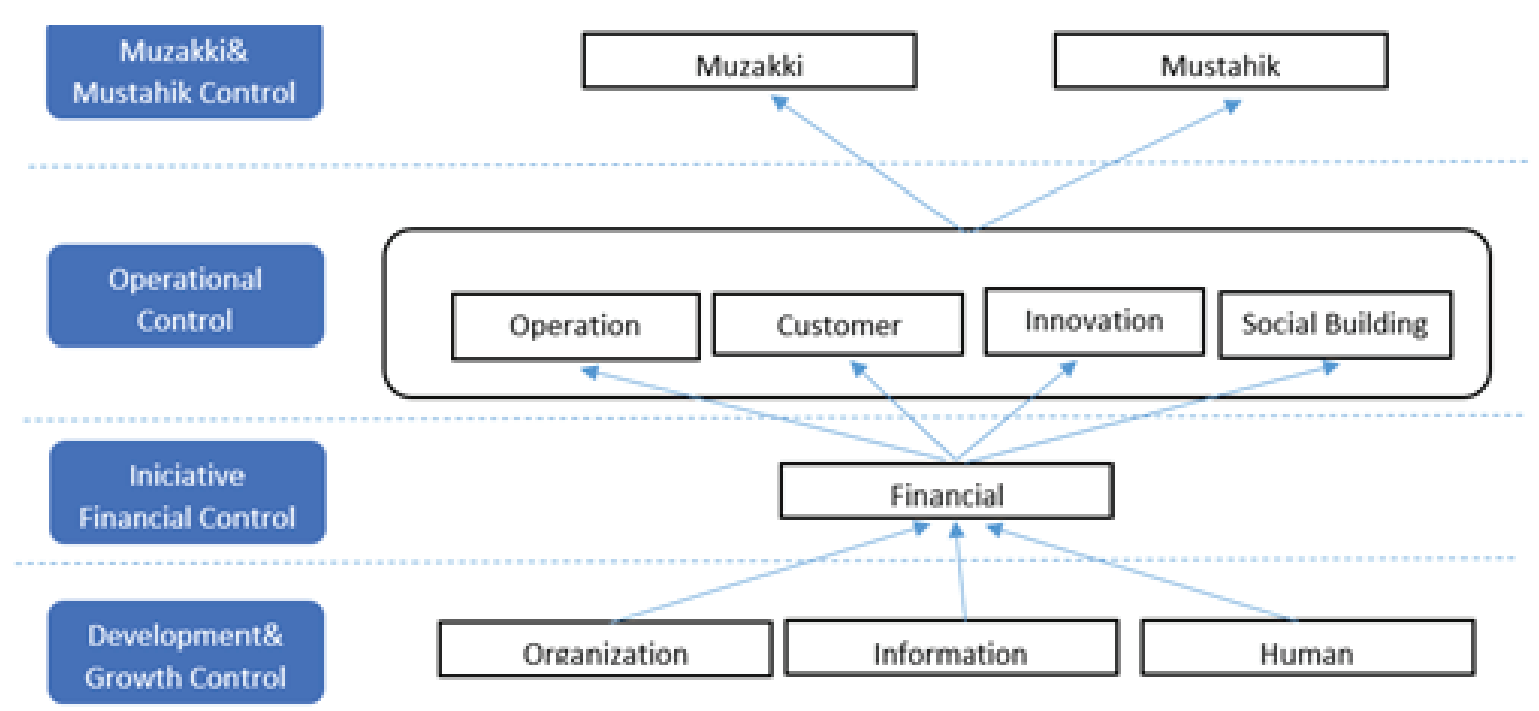

Picture 2. Zakat Scorecard Model

\section{ZAKAT SCORECARD MODEL}

Data structure describes each category that consists of 30 first-order category. Results of the first-order form classification category according Figure 1 into ten second-order themes. Each second-order themes replied findings in the managerial system of zakat management. Figure 2 illustrates that the aggregate first dimension is the development and growth control consists of three themes, namely organization, information, and human. Describes the organization's strategy to build a culture, cooperation, corporate values, and leadership. The information describes how to use the information that is used to collect funds from muzakki. As well as the human is a method to do the training and development of human capital in the organization.

A second dimension Initiative aggregate financial control. The financial aspects of a constituent Zakat Model Scorecard. Financial can be obtained after the organization is able to succeed in doing control system development and organizational improvement. So as to obtain the initial trust of the community. Different financial aspects corresponding profitoriented organizations. Social organizations such as the BAZ and LAZ, do not use the financial as the destination. Interest $\mathrm{LAZ}$ and $\mathrm{BAZ}$ are giving welfare to mustahik through economic empowerment and other social programs. The fourth dimension is Muzakki aggregate and Mustahik Control explained that the final orientation is to provide value to both parties.

The findings obtained by the LAZ and BAZ give value to muzakki zakat calculation may include services, recitals, and other Islamists services relating to zakat. The ability of fulfilling this orientation, can be done through a third dimension, namely aggregate opertional control. In operational control, LAZ and BAZ must be able to effectively manage managerial operations, providing value to customers in the form of zakat services transparent, and effective. Innovation in obtaining funding charity, donation, and shodaqo. As well as innovative in empowering funds from muzakki to mustahik. The fourth theme of operational control, namely the establishment of social islamic building given to muzakki and mustahik. 


\section{Conclusion}

The data processing is done through categorical analysis to produce representative quotes essence serve as the main points in the management of zakat for LAZ and BAZ. The main points are arranged in several categories Zakat Model Scorecard and produced the first phase of the most fundamental to LAZ and BAZ are contained in the internal management and control development category. Stage of development and optimal control if implemented will affect the performance of LAZ and BAZ directly related to trust muzakki. Muzakki confidence on the performance of LAZ and BAZ determine the size of the funds that can be collected, it is then the next stage will affect the Initiative Financial Control in the financial aspect.

Funds collected in this financial aspect, LAZ and BAZ get support so that they can carry out the operations of the institution or enter the operational phase control which is the stage of the distribution of funds to mustahik. Further operational control will affect muzakki stage and mustahik control, which becomes the stage and the main purpose of the existence of LAZ and BAZ. That is the stage where LAZ and BAZ are able to provide better welfare for mustahik and usefulness for muzakki. For mustahik LAZ and BAZ to provide funding and empowerment. As for muzakki, they can receive additional value on participation in paying zakat in the LAZ and BAZ.

\section{IMPLICATION}

\section{Academic Implication}

This concept is the academic implications of the balanced scorecard created by Kaplan and Norton (2014). Critical point that it became the findings of this research is the change in orientation of the organization. Research on zakat management institutions show that the organization is a welfare orientation mustahik and provide value to muzakki and not as the result of research conducted by Kaplan and Norton (2014) on the company's profit oriented financial or profit-oriented companies.

\section{Managerial Implication}

This study is expected to be a recommendation for LAZ and BAZ in making strategy in the management of zakat, donation, and alms. And to improve the efficient, effective and competitive advantages in the sustainability of the organization.

\section{REFERENCES}

Abdullah, Rose. 2012. Zakat Management in Brunei Darussalam: Funding The Economic Activities Of the Poor. Universiti Islam Sultan Sharif Ali

Abu B, Nur Barizah, H. M. 2010. Motivations of Paying Zakat on Income: Evidence from Malaysi. International Journal of Economics and Finance Vol. 2, No. 3

Ali, Ahmad Fahme Mohd, et al. 2015. The Effectiveness OfZakat In Reducing Poverty Incident: An Analysis In Kelantan, Malaysia. Canadian Center of Science and Education 
Amalia, K. M. 2012. Potensi dan Peranan Zakat dalam Mengentaskan Kemiskinan di Kota Medan. Jurnal Ekonomi dan Keuangan, Vol. 1, No.1, Desember .

Anwar, M. 1995. Financing Socio-Economic Development with Zakat Funds. Journal of Islamic Economic vol4 1\&2, 15-32.

Aziz, Asmah Abdul, et al. 2013. The Importance Of Zakat Institutions In Malaysia. The 5 th International Conference on Financial Criminology (ICFC) 2013 "Global Trends in Financial Crimes in the New Economies"

Aziz, Nubani Md and Abd Halim Mohd Noor. 2015. Do Capital Assistance Program by Zakat Institutions Help The Poor? International Accounting and Business Conference, IABC 2015

Beik, Irfan Syauqi. 2008. Fiqh Zakat Kontemporer. Makalah disampaikan pada Seminar dan Pelatihan Zakat yang diselenggarakan Pemerintah Kabupaten Bengkalis pada tanggal 11 Juni 2008.

Kahf, M.. 1990. The Performance of The Institution of Zakah in Theory and Practice. International Conference on Islamic Economics towards 21 st Century. Kuala Lumpur.

Kementrian Agama, D. P. 2012. Pedoman Pengawasan Lembaga Pengelola Zakat. Jakarta: Kementrian Agama.

Pusat Ekonomi dan Bisnis Syariah (PEBS) FE UI, a. C. 2009. Indonesia Zakat and Development Report 2009. Jakarta: Republika. 